\title{
The Effects of Temporary Immigration on Prices of Non Traded Goods and Services
}

\author{
Leila Baghdadi \\ Tunisia Polytechnic School \\ Marion Jansen \\ International Labor Office
}

\begin{abstract}
This paper analyzes the impact of temporary immigration on the prices of nontradable goods and services. It presents a model of a small open economy that produces two goods/services, one tradable and one non tradable. It is assumed that temporary immigrants are confined to work in the non-traded sector and that they are only imperfect substitutes for permanent immigrants and native low skill workers. In our theoretical set-up temporary immigration is predicted to have a negative effect on the prices of non-traded goods and services, while the effect of permanent immigrants depends on the relative low skill domestic labor intensity of the non tradable sector. We test these predictions empirically using a panel dataset of 14 U.S. cities for the period 2000-2006. In line with other recent empirical studies we find that both types of immigration have a negative impact on the

\footnotetext{
*Corresponding address: Leila Baghdadi; LIM (MES cluster), Tunisia Polytechnic School, 2078 La Marsa, Tunisia. Tel: +21671774 611. Fax: +21671748843. Email: leila.baghdadi@malix.univ-paris1.fr./ Marion Jansen; Employment Sector, International Labor Organization, Route des Morillons 4, CH-1211 Geneve 22, Switzerland. Tel: +41(0)227997504. Fax: +41227997562. Email: jansen@ilo.org.

*This paper was written when Marion Jansen held the position of counsellor in the Economic Research and Statistics Division of the World Trade Organization. The opinions expressed in this paper should be attributed to the authors. The paper is not meant to represent the position or opinions of the ILO, the WTO and their respective Members, nor the official position of any staff members and is without prejudice to Members' rights and obligations under the ILO or the WTO.

*Acknowledgements: The authors would like to thank the editor, Lionel Fontagné, Franco Peracchi, Tito Boeri, Michel Beine, Jean-Pierre Laffargue, Mouhoub El Mouhoud and Akiko Suwa-Eisenmann, participants to the WTO PhD Economic Seminar and ETSG for comments on previous versions of this paper. All remaining errors and omissions are the fault of the authors.
}

(C2010-Center for Economic Integration, Sejong Institution, Sejong University, All Rights Reserved.
\end{abstract}


relative price of non-tradable services as a whole. These findings confirm that immigration, like trade and offshoring, has the potential to increase welfare through the reduction of consumer and input prices. When distinguishing individual non tradable sectors, though, we find evidence that permanent immigration increases the price of transport and health services. This finding is in line with the predictions of earlier theoretical work and suggests in the context of our model that these sectors are less low skill domestic labor intensive than tradable goods and services.

- JEL Classification: F22, P42, F16

- Keywords: Temporary Migration, Permanent Migration, H2-b visas, United States of America, Prices, Factor Specific Model.

\section{Introduction}

An old concern, constantly revived, over immigration aliments the current public debate in numerous industrialized countries, including France and the United States. The debate in these countries tends to focus on one main concern: the expected negative impact of immigrants on the wages of competing domestic workers. Not surprisingly, therefore, the relationship between immigrants and domestic wages has also been widely documented in the academic literature, with the relevant empirical literature finding only relatively small negative effects of immigration on domestic wages. ${ }^{1}$

The public debate tends to neglect the potential positive effect immigration has on domestic prices. Indeed, if immigration increases the supply of certain types of labor it is likely to decrease production costs of the goods and services that use this type of labor with negative effects on equilibrium prices. Consumers of the relevant goods and services take advantage of this downward pressure on prices. While the consumer gains from price reductions have been emphasised in the debate on the welfare effects of trade, these potential gains have received far less attention in the debate on the economic effects of migration.

Yet, there appears to be awareness of the potential role immigration can play in this respect, in particular in occupations that natives "are not willing to do" and that cannot be outsourced because they relate to non traded goods and services, like

${ }^{1}$ Borjas et al (1991) and Card (2001). 
construction or housekeeping. The previous US Secretary of labor, Elaine Chao, announced in 2004 in her "Skills to build America's future initiative" 2 that these occupations are expected to see the greatest demand increase over the following years. ${ }^{3}$ Immigration can play a role in smoothing possible supply constraints in the relevant sectors and in this context the public debate has praised the possible advantages of temporary immigration or temporary work permit schemes. ${ }^{4}$ The present paper wants to contribute to this debate by analyzing the effects of temporary immigration on domestic prices of goods and services and by comparing them with the effects of permanent immigration.

Most of the existing theoretical and empirical literature analyzing the effects of immigration on prices has focused on permanent migration. The theoretical literature does not come to firm conclusions as to the sign of the effect of immigration on prices. Instead, this literature shows that the effect significantly depends on two factors: the substitutability between immigrants and comparable domestic worker and the consumption behavior of immigrants.

Neary (1989) demonstrates in a model with permanent immigration, traded and non-traded goods, that an inflow of foreign workers may raise the relative prices of non-traded goods in the labor importing country through increased demand induced by immigration. Neary (1989) states that this paradoxal result occurs if these non traded goods are labor intensive and immigrants have the same consumer behavior as natives (homothetic preferences). In other words, if the effect on demand for final goods is strong enough, it may outweigh the supply effect on factor markets and the net effect of immigration on consumer prices is positive.

The empirical findings by Lach (2007) and Cortes (2008) seem to indicate that this effect is not the most likely outcome in reality. Lach (2007) examines empirically the effects of permanent immigration on prices of traded goods excluding services through demand in Israelian cities and finds that the effect remains negative especially in products where demand is larger. He explains his result by the fact that immigrants have different consumer behavior and will search intensively for lower prices differently from natives. Cortes (2008) provides an empirical assessment of immigrants' effects on the prices of services in US cities. The author finds that a $10 \%$ increase in the share of low skilled immigrants in the

\footnotetext{
${ }^{2}$ See http://www.doleta.gov/business/skilltobuild.cfm.

3"US Jobs: Reach for the Stars...or a Hammer" by Ilana Mercer in WorldNetDaily.com, 11 May 2004.

${ }^{4}$ See, for instance, Mattoo (2005) and the interview with Segolene Royal in El Pais on 17 September 2006.
} 
labor force decreases the price of immigrant intensive services such as housekeeping and gardening by $1.3 \%$ percent and of other non traded goods by $0.2 \%$.

Unlike the previous author who focuses strictly on permanent immigration, Kondoh (1999) presents a model with traded and non traded sectors that allows the author to investigate and compare the effects of permanent and temporary immigration on the relative price of non traded goods. Kondoh (1999) assumes that both types of immigrants are perfect substitutes for domestic low skilled labor but that they differ in their consumption behavior. In particular it is assumed that temporary migrants send their entire income to their home country. In this set-up an increase in the inflow of either type of immigration lowers (raises) the relative price of the non-traded good if the non-traded good is labor (capital) intensive.

The present paper analysis the effects of immigration on the price of services in US cities building on a theoretical framework that enriches Kondoh's (1999) set up in that it takes into account additional differences between temporary and permanent migrants that have been discussed in the relevant literature.

Like Kondoh (1999), we assume that permanent migrants' consumption behaviour is identical to that of natives, whereas temporary migrants send their income to their home countries. The fact that temporary migrants send significant parts of their revenue back home has been documented in studies like Hatzipanayotu (1994) and Rahman (2001).

In addition, we assume that temporary migrants are confined to work in certain sectors, whereas permanent migrants can chose to work where they wish. This assumption reflects a common characteristic of temporary work permit schemes, like the former guest worker scheme in Germany. It also corresponds to the restrictions so called "temporary aliens" face in the United States, as they are assigned to work in relatively low skilled service sector (e.g. hotels, restaurants, domestic helpers and construction). In the US case, these temporary immigrants unlike permanent ones - can change neither their geographic location nor their occupation..$^{5}$ In a recent paper, Bowen and $\mathrm{Wu}(2006)$ consider these facts in their model and treat temporary immigrants as specific to the non-traded sector.

Last but not least we assume that temporary immigrants are not close substitutes of natives whereas permanent aliens are perfect substitutes. This is explained in part, by the assumption discussed before and related to the geographic and sector immobility of temporary immigrants, as indicated in Wendy Carlin (1996) who

${ }^{5}$ Jones and Engerman (2001), for instance, point out: "These transient workers were confined to certain occupations and sectors" and worked mainly in the non traded sector. 
discussed the German guest worker scheme:

until 1969 the jobs filled by foreign workers were concentrated in a few branches of manufacturing and construction... These were unskilled workers and were not close substitutes for German workers.

In addition, the assumption of imperfect substitutability can be justified on grounds of a lower assimilation of temporary immigrants. Indeed, a number of authors ${ }^{6}$ have indicated that temporary immigrants because of their short stay in the host economy cannot assimilate (attain the same qualifications of natives) and hence cannot completely substitute natives.

We show that in our theoretical set-up the effect of temporary immigration on prices of non-tradable is negative while the effect of permanent immigration is ambiguous. Permanent immigration has a negative effect if the non traded sector is more intensive in low skilled labor than the traded sector. Thus our theoretical findings are different from Kondoh (1999). The latter shows that the effects of both types of immigration depend on how intensively they are used in the non traded sector, independently of the factor intensity in the tradable sector. They are in line with Neary's (1989) finding that permanent immigration may raise the price of non-traded goods.

We test our predictions using city level data for the United States for the period 2000-2006. In the regressions covering all non-tradable sectors, our findings are in line with those in Cortes (2008) and suggest that both low skilled temporary and permanent immigrants have a significantly negative impact on the price of nontraded goods. When running regressions for individual sectors, though, we find that permanent immigration increases the prices of transport services and health services.

The rest of this paper is structured as follows. Section II presents our theoretical framework for analysing the effects of temporary and permanent migrants on prices of non-traded goods and services. Section III describes the data that will be used in the empirical analysis with a particular focus on the characteristics of temporary and permanent migrants. Section VI presents our empirical analysis and section $\mathrm{V}$ concludes.

${ }^{6}$ Pischke, J.-S., 1992, Bauer et al (2000). 


\section{Theoretical Framework}

\section{A. Setup}

Consider a small open economy that produces two goods or services, one traded (T) and one non-traded (NT). There are three factors of production: high-skilled native labor $(\mathrm{H})$, low-skilled labor (permanent immigrants I and native low skilled labor L), and low skilled temporary immigrants (TM).

We assume that high skilled native labor is specific to the traded sector, low skilled temporary immigrants are specific to the non-traded sector and low skilled natives and permanent immigrants are mobile between the two sectors. ${ }^{7}$ This would, for instance, reflect that permanent and temporary immigrants compete for jobs in housekeeping and construction, while native low skilled workers and permanent immigrants compete for jobs in certain manufacturing sectors. The traded good production function is Cobb-Douglas:

$$
T=\left(L_{T}+I_{T}\right)^{\beta} H^{1-\beta}
$$

Where $0<\beta<1$ is the constant elasticity of substitution between the aggregate low skilled labor (native and immigrants) and high skilled labor. Equation (1) indicates that permanent immigration and natives are assumed to be perfect substitutes. While equation (2) indicates that temporary immigrants are assumed to be imperfect substitutes to both permanent immigrant and natives.

$$
N T=\left(L_{N T}+I_{N T}\right)^{\alpha} T M^{1-\alpha}
$$

Where $0<\alpha<1$ is the constant elasticity of substitution between the aggregate low skilled labor (native and immigrants) and temporary low skilled immigrants. The economy admits a representative consumer with a Cobb-Douglas type utility:

$$
U=T^{\sigma} N T^{1-\sigma}
$$

We assume that only native and permanents migrants consume both goods. Temporary immigrants save their income and remit their savings to their home

${ }^{7}$ Cortes (2008), instead, assumes that low skilled permanent immigrants and natives are specific to the non traded sector while high skilled workers are mobile between the two sectors. 
countries. We suppose that all markets are competitive. The economy takes the price of the tradable good $P_{t}$ which is normalized to one, as given. All this implies that our model is a specific factor model but with particular assumptions as to the consumption behavior of one of the sector specific production factors.

\section{B. Equilibrium}

Utility maximization leads consumers, permanent low skilled immigrants and native workers, to spend a fraction $\sigma$ of their income in the consumption of the traded good and $1-\sigma$ in the consumption of the non-traded good. This condition plus market clearing in the non-traded market imply that the following equation holds:

$$
N T=\frac{(1-\sigma)\left(w_{H} \bar{H}+w_{L} \bar{L}+w_{I} \bar{I}\right)}{P_{N T}}
$$

where the left side of equation (4) represents the total supply of the non traded goods in equilibrium. $\bar{H}, \bar{L}$ and $\bar{I}$ are respectively the total amount of high skilled native workers, low skilled native workers and permanent lows skilled immigrant workers.

The following equilibrium equations result from the condition that all factors are paid the value of their marginal product in competitive markets and that the marginal product of low skilled workers (mobile natives and permanent immigrants) should be equal in both sectors:

$$
\begin{gathered}
w_{H}=(1-\beta)\left[\left(L_{T}+I_{T}\right) / \bar{H}\right]^{\beta} \\
w_{I}=w_{L}=\beta\left(\bar{H} /\left(L_{T}+I_{T}\right)\right)^{1-\beta} \\
w_{I}=w_{L}=\alpha\left[\overline{T(M)} /\left(L_{N T}+I_{N T}\right)\right]^{1-\alpha} * P_{N T} \\
w_{N T}=(1-\alpha)\left[\left(L_{N T}+I_{N T}\right) / \overline{T M}\right]^{\alpha} * P_{N T}
\end{gathered}
$$

The right hand side of equations (5), (6), (7) and (8) represent the value of the marginal product of high skilled natives, low skilled natives and permanent immigrants and temporary immigrants. As pointed out in equation (6) and (7), permanent immigrant wages and low skilled natives wages are equal because they are assumed perfect substitutes. 
From equations (4), (6) and (7) we find how domestic low skilled labor is allocated across sectors in equilibrium:

$$
\bar{L}+\bar{I}=\frac{\beta}{\alpha} \frac{1-\sigma}{\sigma}\left(L_{N T}+I_{N T}\right)
$$

Hence, we obtain the equation of equilibrium of the price of the non-traded good:

$$
P_{N T}=A * \bar{H}^{1-\beta} *(\bar{L}+\bar{I})^{\beta-\alpha} * \overline{T M}^{\alpha-1}
$$

Where $\mathrm{A}^{8}$ is a function of $\alpha, \sigma$ and $\beta$. Equation (10) shows that the relative price of the non traded good depends positively on the total supply of the high skilled labor. An increase in this factor will raise the price of the non-traded good.

Equation (10) shows that an increase in the supply of temporary immigrants has a negative effect on the price of non-traded goods. However, the effect of permanent immigration appears ambiguous and depends on the parameters $\alpha$ and $\beta$. An increase in permanent immigrants will have a positive effect on non-tradable prices if $\beta>\alpha$ : the traded sector is more intensive in low skilled domestic workers (both natives and permanent immigrants) than the non-traded sector. An increase in permanent immigrants will have a negative effect on non-tradable prices if $\beta<\alpha$ : the non-traded sector is more intensive in low skilled domestic labor (permanent immigrant and natives) than the traded sector.

In the next section, we will implement empirically the log linear form ${ }^{9}$ of equation (10) in order to test our theoretical findings.

\section{Empirical Implementation:}

\section{A. Temporary Immigration Flows in the United States}

Recently, the US immigration system experienced a rise in the temporary admission of people. A large percentage of these temporary admissions in any

\footnotetext{
${ }^{8} \mathrm{~A}$ is equal to $(1-\sigma)\left[\frac{\beta}{\alpha} \frac{1-\sigma}{\sigma}\right]^{\beta}\left[1-\beta+\frac{\alpha}{\beta}\left(\frac{\alpha \sigma+\beta(1-\sigma)}{1-\sigma}\right)\right]\left[\frac{\alpha \sigma}{\alpha \sigma+\beta(1-\sigma)}\right]^{\beta-\alpha}$

${ }^{9}$ This is the $\log$ linear form of equation (12): In $P_{N T}=\ln \mathrm{A}+(1-\beta) \ln \bar{H}+(\beta-\alpha)(\bar{L}+\bar{I})$ $+(\alpha-1) \ln \bar{T} \bar{M}$
} 
fiscal year are visitors for leisure. For instance, in 2002, 71.5\% of non-immigrants entered as visitors for pleasure and $15.68 \%$ as temporary visitors for business. Although tourists have been the most numerous temporary class of admission to the United States, there has been an expansion in the category of temporary workers. These workers are admitted under several types of visas. For example, H$1 \mathrm{~B}$ visas require professional, college education, skilled and/or equivalent experience, $\mathrm{H}-1 \mathrm{C}$ applies to registered nurses or $\mathrm{H}-2 \mathrm{~B}$ applies to temporary or seasonal non-agricultural workers. In this paper, we are interested in the latter type of visas. Indeed, the present study deals with temporary less skilled immigrant in services related activities and this mach perfectly the $\mathrm{H}-2 \mathrm{~B}$ visas: Similarly to $\mathrm{H}-$ $1 \mathrm{~B}$ or $\mathrm{H}-1 \mathrm{C}$ workers, a large proportion of the $\mathrm{H}-2 \mathrm{~B}$ workers are mainly active in services related occupations but unlike the $\mathrm{H}-1 \mathrm{~B}$ and $\mathrm{H}-1 \mathrm{C}$, the $\mathrm{H}-2 \mathrm{~B}$ qualification criteria do not require education. In fact, the $\mathrm{H}-2 \mathrm{~B}$ program permits employers to hire foreign workers to come to the U.S. and perform temporary non-agricultural work, which may be one-time, seasonal, peak load or intermittent. The proposed job must be less than one year; and there must be no qualified and willing U.S. workers available for this job. There is a 66,000 per year limit on the number of foreign workers who may receive $\mathrm{H}-2 \mathrm{~B}$ status during each USCIS fiscal year (October through September).

Employers who want to hire an H-2B worker must follow several steps. First, the employer must submit a labor condition application (LCA) to the U.S. Department of Labor and to the State Workforce Agency (SWA) that includes the position, wage, and benefits to be offered to the H-2B worker. The LCA requires employers to determine the prevailing wage for the position in the geographic area and the actual wage paid by employers to other individuals with similar experience and qualifications for the relevant type of work. The Department of Labor reviews the LCA for accuracy and completeness and will grant certification if he finds that qualified persons in the United States are not available and that the terms of employment will not adversely affect the wages and working conditions of workers in the United States similarly employed. After the certification of the LCA, the employer files a visa petition with the U.S. Immigration and Naturalization Service (INS). The petition requires that the employer provide documents substantiating the potential worker's education and qualifications. The INS makes the final decision on whether a foreigner is qualified for an $\mathrm{H}-2 \mathrm{~B}$ visa. 


\section{B. Data}

\section{Temporary Immigration Data}

The US Department of Labor makes data available from the Labor Condition Applications (LCAs) filled by employers who sought to hire temporary H-2B workers during the 2000-2006 fiscal years. The data includes the employers' name and locations, the wage rates offered, the number of visas sought, the occupations in which visas holders will be employed, and whether the LCA would be certified or denied. As underlined by Zavodny (2003) for the H-1B case, there are both disadvantages and advantages to using the LCA data to examine H-2Bs. On the one hand, LCA present the main disadvantage that employers file LCAs for several times (Lowell 1999). On the other hand, the LCA data are the only available source of detailed information about $\mathrm{H}-2 \mathrm{~B}$ visas (i.e. occupations, city of employment etc.).

\section{Permanent Immigration Data}

This paper uses the Integrated Public Use Microdata Series, Current Population Survey, for the years 2000 to 2006 to compute the share of low skilled immigrant workers for each city and the share of low skilled immigrant workers for each city and type of occupation. The share of low skilled immigrant workers is defined as total low skilled immigrant workers divided by total immigration in the US city. Low skilled is defined as those who have not completed high school. An immigrant is defined as someone who reported being a naturalized citizen or not being a citizen. This analysis is restricted to people aged between 16-64 who report being in the labor force. We also use the Immigration and Naturalization Service (INS). This data source documents annual admission of foreign-born individuals as permanent residents in the United States as well as their country of origin and their intended city of residence. These data do not take into account temporary residents or illegal foreigners. Therefore, we will use these data as principal indicator of permanent immigrants' inflows for the period 2000-2006. We use data from the INS and IPUMS-CPS to compute low skilled permanent immigrant workers by city. The latter is constructed as the product of the share of low skilled immigrant and the flows of permanent immigrant in the U.S. city. We construct similarly the low skilled permanent immigrant workers for each city and group of occupation. 


\section{Price Data ${ }^{10}$}

We use Economist Intelligence Unit City data that include information on prices in over 130 cities in nearly 90 countries. Surveys are conducted twice a year in June and December and collected for more than 50,000 individual prices are collected. The EIU City Data gathers detailed information on the cost of more than 160 items--from food, toiletries and clothing to domestic help, transport and utility bills--in every city. Survey prices are gathered and listed from three types of stores: supermarket, medium-priced retailers and more expensive specialty shops. ${ }^{11}$

For the purpose of our study, we identify 53 non traded goods and prices in the following categories: utilities, household supplies, personal care, domestic help, recreation, transport, education, health and sports and business trip costs. ${ }^{12}$

\section{Other variables}

We use also other variables in order to control for cities amenities such as the evolution of population and income at the Metropolitan level. These data are taken from the Bureau of Economic Analysis (BEA) Regional Information System (REIS).

We also add unemployment rates at the metro area level from the Bureau of Labor Statistics (BLS).

\section{Descriptive Statistics:}

\section{Permanent and Temporary Immigrants per city}

Figures 1 and 2 show the flows of low skilled temporary and permanent immigration per city over the period 2000-2006.

We can distinguish two types of cities. On the one hand, some cities receive significant flows of both permanent and temporary immigrants. This is the case of Washington, Boston and New York. On the other hand, other cities (for example: Minneapolis, Seattle, Honolulu etc.) attract a lot of permanent immigration but hardly any temporary foreign worker. The cities in the first category including San

\footnotetext{
${ }^{10}$ Cortes (2008) used a confidential dataset (RDB) on prices dataset from the Bureau of Labor Statistics (BLS). The EIU CityData, as we explained, covers many prices and largely the prices needed for our analysis.

${ }^{11}$ The original aim of this data is to enable human resources like managers and expatriate executives to compare prices in over 130 cities and calculate fair compensation policies for relocating employees.

${ }^{12}$ Our definition of non-tradable services thus differs from those in Jensen and Kletzer (2005) and Blinder (2009) that are based on different datasets and use occupational or industry classifications.
} 
Figure 1. Flows of permanent immigration by city (in log)

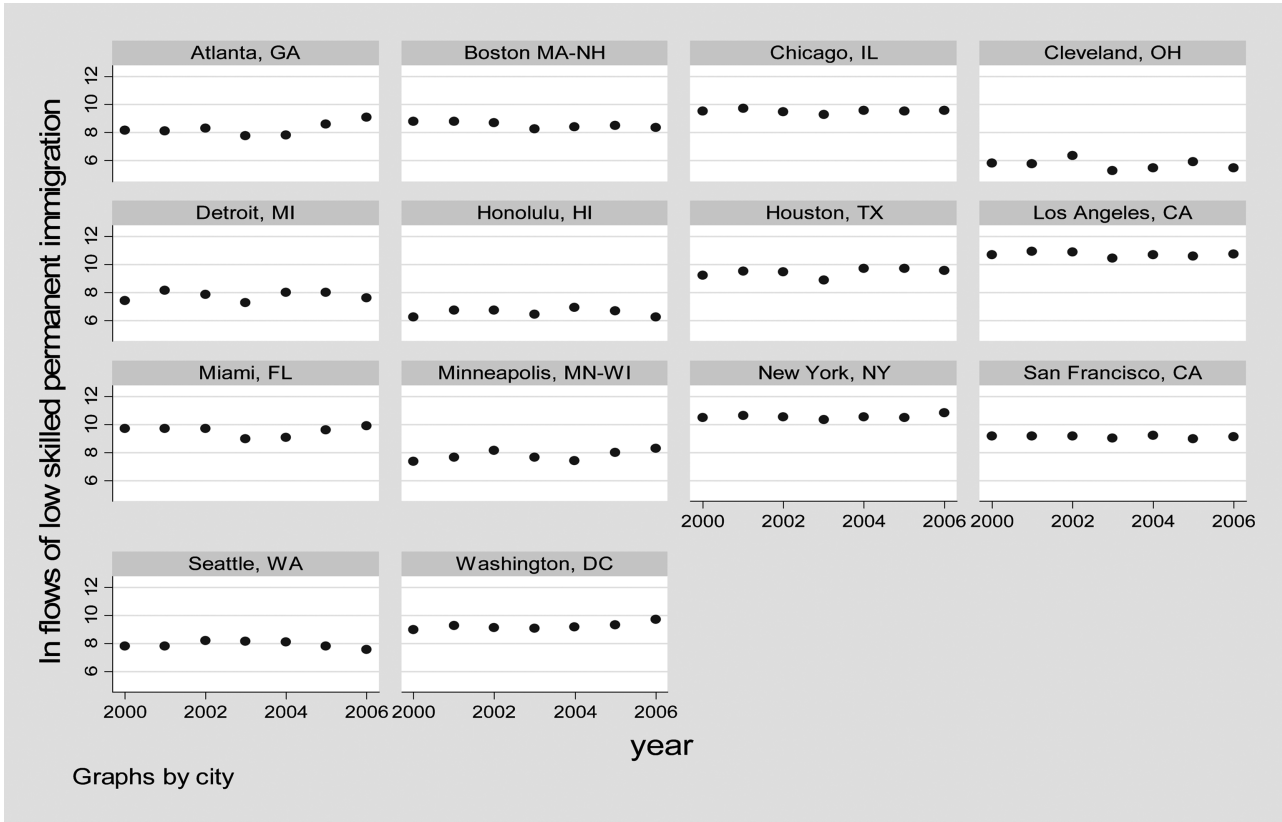

Figure 2. Flows of temporary immigration by city (in $\log$ )

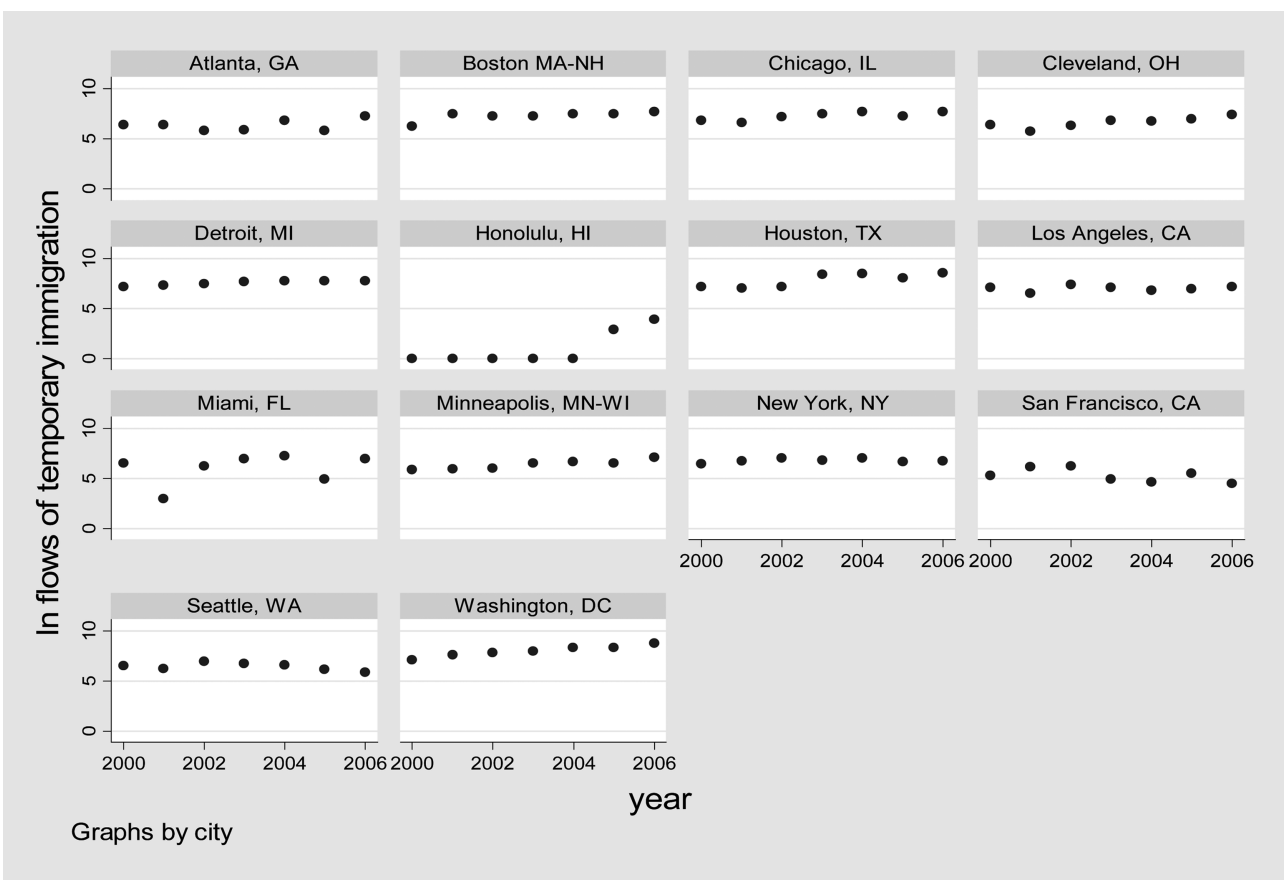


Francisco, Boston and Chicago are called consumer cities by Glaeser et al (2001). As mentioned by these authors, these cities have relatively successful industries that have done well in the information economy. The authors suggest that these cities are attractive for the high skilled mainly because of the large and rich set of consumption activities and services (in recreation, museums, restaurants, hotels, sports, education, etc.). Hence, these cities highly demand low skilled foreigners, permanent and temporary, to fill employment in these non-tradable sectors.

\section{Permanent and Temporary Immigrants per occupation}

Figure 3 shows the most intensives occupations in both low skilled immigrants and natives workers and reflects the share of low skilled natives and immigrants in the total labor force respectively used in these fields. We observe that almost all the industries intensive in low skilled natives are also intensive in low skilled immigrants except the transportation services and the construction and extraction fields. Whereas the former is more intensive in low skilled natives, the latter is more intensive in less skilled immigrants. Overall low skilled permanent immigrants and low skilled natives appear to be present at the same level in different industries. This conclusion gives some support to the theoretical

Figure 3. Share of Less skilled Immigrant vs. natives in the most intensives less skilled Occupations

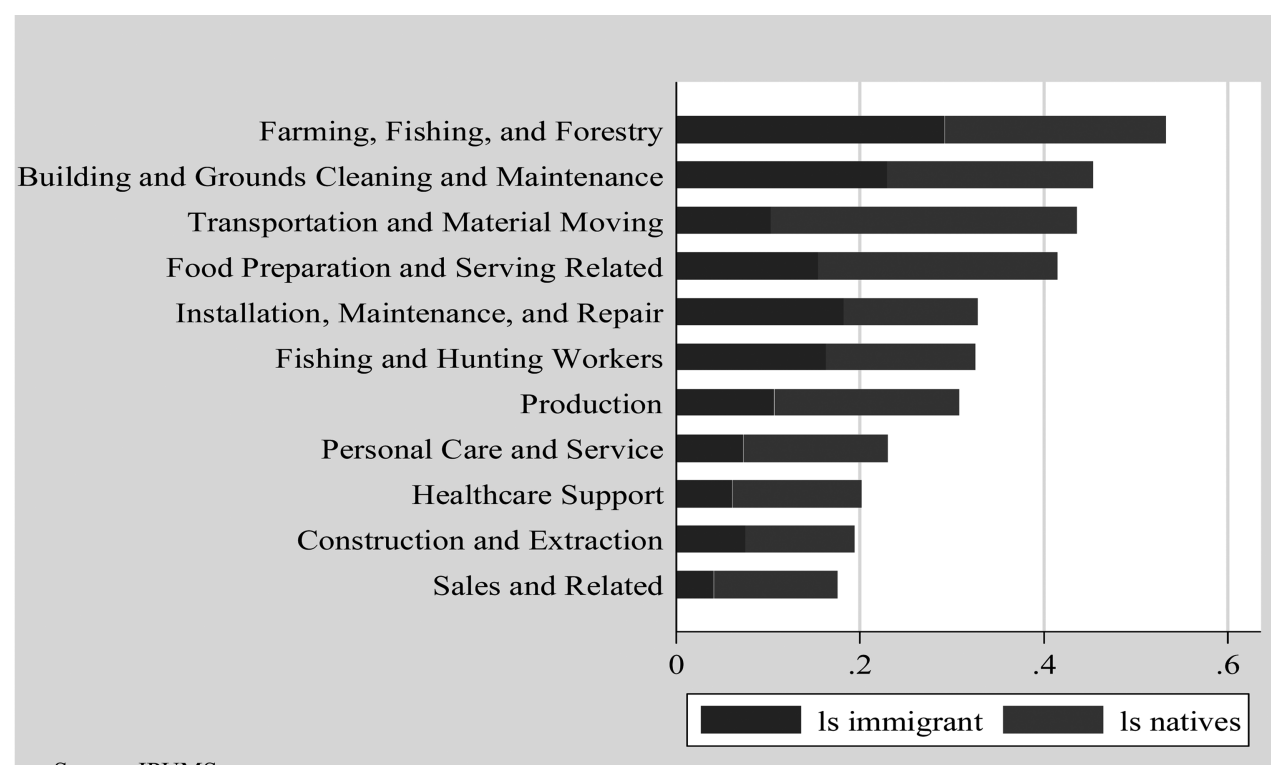


Figure 4. Share of Less skilled Permanent vs. Temporary Immigrant in the most intensives less killed Occupations

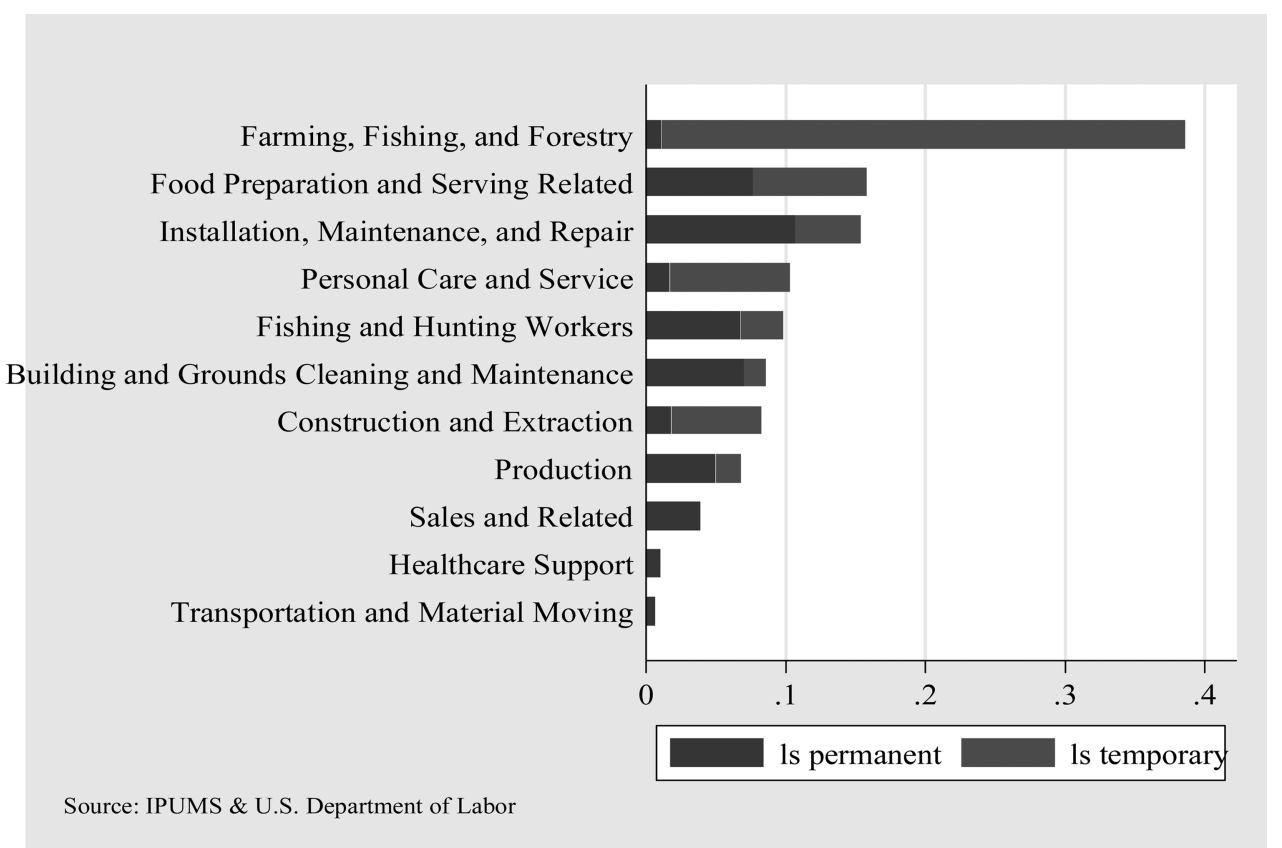

hypothesis that permanent immigrants and natives can be considered perfect substitutes.

Figure 4 compares the share of low skilled immigrants working in a given sector in the total low skilled permanent immigration and the share of temporary immigrants in the total flow of temporary immigration working in the same sector. Two observations are drawn from these figures. Temporary immigrants are more likely to work in services related sectors (i.e. Personal care services, Food preparation and services related etc) than permanent immigrants with the exception of farming, fishing, forestry and related occupations. Permanent immigrants, instead, are more likely to work in the traded sector (production occupation, sales and related etc). ${ }^{13}$

Figure 5 compares the share of low skilled natives working in a given sector in the total of low skilled natives and the corresponding share of temporary immigrants. Figure 4 and 5 look very similar which confirms the idea that natives

\footnotetext{
${ }^{13}$ We can also show the distribution of temporary immigrants in other sectors and remark that they are more intensively used in the low skilled immigration sectors mainly because they are low skilled workers too.
} 
Figure 5. Share of Less skilled Native vs. Temporary Immigrant in the most intensives less skilled Occupations

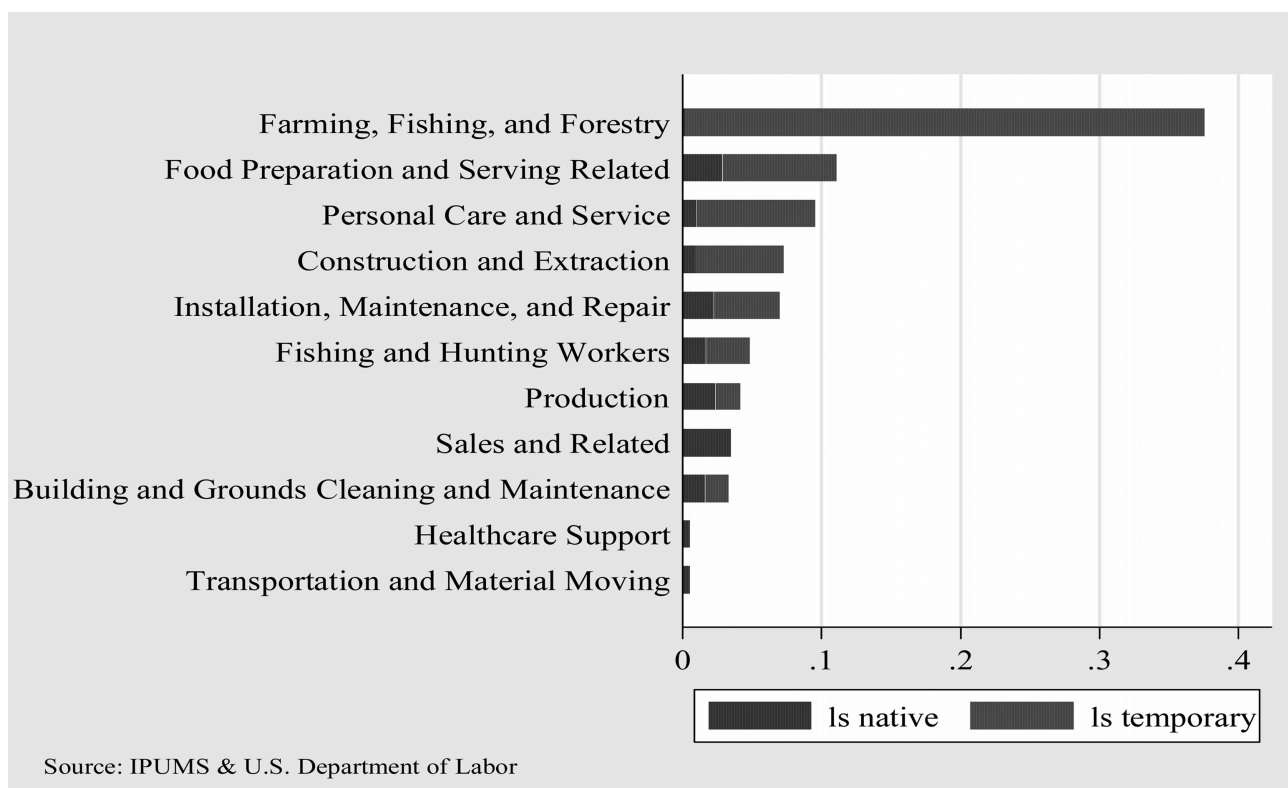

and permanent immigrants are stronger substitutes than natives and guest workers.

\section{Temporary Immigrants per city and per occupation}

As shown in figure 4, temporary low skilled foreign workers are essentially concentrated in services sectors. However, the farming sector (related to tradable sector) appears to be the sector most intensive in this type of workers. In cities like San Diego and San Francisco temporary immigrants work exclusively in this sector. Other cities in our sample fulfill demand for temporary foreign labor in four main sectors: installation, maintenance and repair occupations in Seattle and New York, construction and extraction sectors in Philadelphia and Cleveland, food preparation and serving related sectors in Chicago, Denver, Minneapolis, Milwaukee, Tampa and Portland and personal care and services is the most important sector employing this type of workers in cities like Boston, Detroit, Houston, Washington, Atlanta, St Louis, Miami, Los Angeles and Kansas City. Because of the hypothesis in our model that less skilled temporary workers are specific to the non-tradable services sector, we ignore occupations involved in farming, production and forestry occupations in our empirical analysis. 


\section{Empirical specification and results}

The model presented in section 2 is applied to 53 prices of non-tradable goods and services for 14 American cities during the period 2000-2006. The estimated specifications are derived from the log linear form of equation (10):

$$
\begin{gathered}
\ln P_{s c t}=\gamma_{1}+\gamma_{2} \ln T M_{c t}+\gamma_{3} \ln I_{c t}+\gamma_{4} \ln P O P_{c t}+\gamma_{5} \ln U R_{c t} \\
+\gamma_{6} \ln P I N_{c t}+F E_{s}+F E_{t}+\varepsilon_{s c t}
\end{gathered}
$$

Where $s$ stands for non traded sectors, $c$ for city and $t$ for year. TM represents the low skilled temporary immigration and $I$ stands for low skilled permanent immigration. We use population of the city, $P O P$, as a proxy for low skilled, $L$ and high skilled native workers $H$. Other variables are added to our specification such as income per capita, $P I N$, and unemployment rate, $U R$, in order to monitor for city economic characteristics. We also include time, $F E_{t}$, and sector fixed effects, $F E_{s}$, in our regressions to control respectively for trend variation and sector specific characteristics while correcting the standard errors to be heteroskedasticity robust.

Columns 1 and 2 in Table 1 show results for ordinary least squares estimations. Column 1 shows that both permanent and temporary low skilled immigration have a negative effect on prices of non-tradable goods and services. Following our model conclusions, this result indicates that non-tradable sector is more intensive in low skilled domestic labor (permanent immigrants and natives) than the tradable sector. The size of the city approximated by their population has a downward effect on the prices of non tradable goods and services. In the other hand, incomes increase those same prices. Finally, in most specifications unemployment rate does not significantly affect prices. In column 2 , we use total permanent immigration instead of low skilled permanent one. Temporary immigration still has a negative effect on non-tradable good's prices in this specification. However, total permanent immigration increases prices in contrast to low skilled one.

Estimations of the fixed effects model displayed in column 3 and 4 show the same results for temporary and permanent immigration. The downward effect of the city's population and the positive effect of incomes on prices are supported by our results.

In Table 2, we run our specification for each year within the period 2000-2006. Findings presented in Table 2 support the negative effect of temporary immigration for the years 2000, 2001, 2002, 2003 and 2004. Temporary immigration does not have significant effects on prices in the last two years. In the other hand, permanent 
Table 1. Prices of non-traded goods, permanent and temporary immigration

\begin{tabular}{lcccc}
\hline & {$[1]$} & {$[2]$} & {$[3]$} & {$[4]$} \\
\hline Model & OLS & OLS & FE & FE \\
\hline In temporary immigrants & $-0.0290^{* * *}$ & $-0.0187^{* * *}$ & $-0.0291^{* * *}$ & $-0.0187^{* * *}$ \\
& {$[0.004]$} & {$[0.0044]$} & {$[0.0042]$} & {$[0.0045]$} \\
In low skilled permanent immigrants & $-0.0188^{* *}$ & & $-0.0190^{* *}$ & \\
& {$[0.0081]$} & & {$[0.0085]$} & \\
In permanent immigrants & & $0.0480^{* * *}$ & & $0.0485^{* * *}$ \\
ln population & & {$[0.015]$} & & {$[0.015]$} \\
& $-0.262^{* * *}$ & $-0.286^{* * *}$ & $-0.263^{* * *}$ & $-0.287^{* * *}$ \\
In unemployment rate & {$[0.048]$} & {$[0.048]$} & {$[0.048]$} & {$[0.048]$} \\
ln personal income & 0.0406 & $0.0661^{* *}$ & 0.0362 & $0.0621^{* *}$ \\
Constant & {$[0.03]$} & {$[0.03]$} & {$[0.031]$} & {$[0.03]$} \\
& $0.449^{* * *}$ & $0.363^{* * *}$ & $0.451^{* * *}$ & $0.364^{* * *}$ \\
\hline Observations & {$[0.047]$} & {$[0.049]$} & {$[0.047]$} & {$[0.048]$} \\
\hline R-squared & $-2.141^{* * *}$ & $-0.882^{* * *}$ & 0.062 & $1.328^{* * *}$ \\
\hline Number of id & {$[0.28]$} & {$[0.31]$} & {$[0.29]$} & {$[0.31]$} \\
\hline Robust & 4836 & 4836 & 4836 & 4836 \\
\hline
\end{tabular}

Robust standard errors in parentheses

$* * * \mathrm{p}<0.01, * * \mathrm{p}<0.05, * \mathrm{p}<0.1$

Time and sector fixed effects included in all regressions

immigration has a significant and negative effect only in these last two years. Similarly to our previous findings in Table 1, city's size decreases prices of non traded goods and services while incomes increase them. Unemployment rate have ambiguous effects. It increases prices in the first three years but have a negative effect on the prices of non traded goods and services in the last two years.

We turn next to the effects of temporary and permanent immigration for each sector of non tradable goods and services. We classify prices of non traded goods and services in our panel into 9 sectors (see Appendix A): Utilities, laundry, cleaning, drying and pressing (laundry); personal care and services (personal care); food preparation and serving (food); arts, design, entertainment; sports and medias; transport and material moving; education, training and library (education); healthcare practitioners and technical healthcare support (health) and telephone. In the following text, we will refer to these sectors respectively as laundry, personal care, food, entertainment, transport, education, health and telephone. 
Table 2. Prices of non-traded goods, permanent and temporary immigration by year

\begin{tabular}{lccccccc}
\hline & {$[1]$} & {$[2]$} & {$[3]$} & {$[4]$} & {$[5]$} & {$[6]$} & {$[7]$} \\
\cline { 2 - 7 } Year & 2000 & 2001 & 2002 & 2003 & 2004 & 2005 & 2006 \\
\hline ln temporary & $-0.0314^{* * *}$ & $-0.0495^{* * *}$ & $-0.0367^{* * *}$ & $-0.0202^{*}$ & $-0.0171^{*}$ & -0.0114 & -0.00153 \\
immigrants & {$[0.012]$} & {$[0.012]$} & {$[0.011]$} & {$[0.011]$} & {$[0.0099]$} & {$[0.014]$} & {$[0.013]$} \\
ln low skilled & 0.000769 & $-0.0392^{*}$ & -0.00257 & -0.0176 & -0.0277 & $-0.0871^{* * *}$ & $-0.129^{* * *}$ \\
permanent & {$[0.024]$} & {$[0.024]$} & {$[0.026]$} & {$[0.020]$} & {$[0.017]$} & {$[0.028]$} & {$[0.027]$} \\
immigrants & & & & & & & \\
ln population & $-0.288^{* *}$ & $-0.380^{* * *}$ & $-0.291^{* *}$ & -0.214 & $-0.301^{* *}$ & $-0.255^{*}$ & -0.187 \\
& {$[0.14]$} & {$[0.14]$} & {$[0.13]$} & {$[0.14]$} & {$[0.14]$} & {$[0.13]$} & {$[0.13]$} \\
ln unemployment & $0.301^{* * *}$ & $0.229^{* *}$ & $0.231^{* *}$ & 0.0475 & -0.03 & $-0.239^{* * *}$ & $-0.444^{* * *}$ \\
rate & {$[0.090]$} & {$[0.099]$} & {$[0.100]$} & {$[0.089]$} & {$[0.085]$} & {$[0.085]$} & {$[0.083]$} \\
ln personal income & $0.414^{* * *}$ & $0.605^{* * *}$ & $0.445^{* * *}$ & $0.401^{* * *}$ & $0.508^{* * *}$ & $0.559^{* * *}$ & $0.594^{* * *}$ \\
Constant & {$[0.13]$} & {$[0.14]$} & {$[0.13]$} & {$[0.15]$} & {$[0.13]$} & {$[0.13]$} & {$[0.12]$} \\
& $-1.561^{*}$ & $-3.287^{* * *}$ & $-2.035^{* *}$ & $-2.038^{* *}$ & $-2.518^{* * *}$ & $-3.380^{* * *}$ & $-4.508^{* * *}$ \\
\hline Observations & {$[0.80]$} & {$[0.90]$} & {$[0.79]$} & {$[0.84]$} & {$[0.73]$} & {$[0.77]$} & {$[0.82]$} \\
\hline R-squared & 690 & 681 & 683 & 682 & 688 & 701 & 711 \\
\hline
\end{tabular}

Robust standard errors in parentheses

$* * * \mathrm{p}<0.01,{ }^{* *} \mathrm{p}<0.05,{ }^{*} \mathrm{p}<0.1$

Sector fixed effect included in all regressions

We did this classification in order to facilitate the matching of prices sectors to the corresponding occupational group of workers. Table 3 display results for these sectors. Temporary immigration increases significantly the prices of the utilities services but decreases prices of the laundry services, food preparation and serving, education and health services. The increase of the prices in the utilities sector could be explained by the fact that temporary immigrants consume utilities services. Low skilled permanent immigration has more controversial effects on prices. Indeed, it increase prices of the transport and health services but decrease the prices of food preparation and serving, laundry, entertainment and education services. The opposite effect of temporary and permanent immigrants on the prices of health services is very interesting: whereas temporary immigrants decrease these prices, permanent immigrants increase them. This result might be explained by the fact that permanent immigrants consume more than temporary immigrants health services and it suggests that temporary immigrants have less consequences on the health system of the receiving country. The same opposite result is found for transport services suggesting that temporary immigrants are rare users of these 
Table 3. Prices of non traded goods, permanent and temporary immigration by sector

\begin{tabular}{lccccccccc}
\hline \multirow{1}{*}{ Sector } & {$[1]$} & {$[2]$} & {$[3]$} & {$[4]$} & {$[5]$} & {$[6]$} & {$[7]$} & {$[8]$} & {$[9]$} \\
\cline { 2 - 9 } & utilities & laundry & personal care & food & entertainment & transport & education & health & telephone \\
\hline In temporary & $0.0273^{*}$ & $-0.0420^{* * *}$ & -0.0112 & $-0.0466^{* * *}$ & -0.0133 & 0.00384 & $-0.0235^{* *}$ & $-0.0925^{* * *}$ & 0.0115 \\
immigrants & {$[0.016]$} & {$[0.0073]$} & {$[0.0074]$} & {$[0.0074]$} & {$[0.013]$} & {$[0.011]$} & {$[0.012]$} & {$[0.014]$} & {$[0.018]$} \\
ln low skilled & 0.0291 & $-0.0530^{* * *}$ & 0.014 & $-0.0645^{* * *}$ & $-0.0528^{*}$ & $0.139^{* * *}$ & $-0.0977^{* * *}$ & $0.0576^{* *}$ & -0.0475 \\
permanent & {$[0.038]$} & {$[0.014]$} & {$[0.015$} & ]$[0.015]$ & {$[0.027]$} & {$[0.024]$} & {$[0.022]$} & {$[0.024]$} & {$[0.040]$} \\
immigrants & $-0.700^{* * *}$ & $0.197^{* *}$ & $-0.632^{* * *}$ & $-0.601^{* * *}$ & -0.255 & -0.195 & -0.142 & $-0.473^{* * *}$ & -0.0304 \\
ln population & {$[0.18]$} & {$[0.098]$} & {$[0.085]$} & {$[0.085]$} & {$[0.16]$} & {$[0.14]$} & {$[0.12]$} & {$[0.15]$} & {$[0.29]$} \\
& $0.385^{* * *}$ & $-0.110^{*}$ & $0.281^{* * *}$ & 0.0522 & 0.0706 & $0.241^{* * *}$ & $-0.295^{* * *}$ & 0.108 & -0.119 \\
ln unemployment & {$[0.14]$} & {$[0.062]$} & {$[0.051]$} & {$[0.056]$} & {$[0.085]$} & {$[0.079]$} & {$[0.10]$} & {$[0.096]$} & {$[0.14]$} \\
rate & $0.578^{* * *}$ & 0.000854 & $0.711^{* * *}$ & $0.859^{* * *}$ & $0.456^{* *}$ & 0.117 & $0.593^{* * *}$ & $0.641^{* * *}$ & 0.0808 \\
ln personal income & {$[0.19]$} & {$[0.092]$} & {$[0.083]$} & {$[0.081]$} & {$[0.17]$} & {$[0.14]$} & {$[0.12]$} & {$[0.15]$} & {$[0.28]$} \\
Constant & $2.917^{* *}$ & $-1.768^{* * *}$ & $3.208^{* * *}$ & $-4.114^{* * *}$ & $-2.236^{* *}$ & $6.920^{* * *}$ & $-1.423^{* *}$ & -0.208 & $2.571^{*}$ \\
& {$[1.27]$} & {$[0.53]$} & {$[0.52]$} & {$[0.51]$} & {$[1.00]$} & {$[0.85]$} & {$[0.64]$} & {$[0.84]$} & {$[1.43]$} \\
\hline Observations & 276 & 784 & 782 & 686 & 560 & 770 & 865 & 290 & 117 \\
\hline R-squared & 0.56 & 0.86 & 0.98 & 0.98 & 0.91 & 0.98 & 0.86 & 0.45 & 0.98 \\
\hline
\end{tabular}

Robust standard errors in parentheses

$* * * \mathrm{p}<0.01, * * \mathrm{p}<0.05, * \mathrm{p}<0.1$

Time and sector fixed effects included in all regressions 
Table 4. Prices of non traded goods, permanent and temporary immigration by sector

\begin{tabular}{|c|c|c|c|c|c|c|c|c|c|}
\hline & {$[1]$} & {$[2]$} & [3] & {$[4]$} & [5] & [6] & [7] & [8] & [9] \\
\hline Sector & utilities & laundry & $\begin{array}{l}\text { personal } \\
\text { care }\end{array}$ & food & $\begin{array}{c}\text { entertain- } \\
\text { ment }\end{array}$ & transport & education & health & telephone \\
\hline ln temporary & 0.0292 & $-0.0447^{* * *}$ & -0.0102 & $-0.0460^{* * *}$ & -0.0145 & -0.00298 & $-0.0245^{* *}$ & $-0.0889^{* * *}$ & 0.00429 \\
\hline immigrants & {$[0.019]$} & {$[0.0070]$} & {$[0.0081]$} & {$[0.0074]$} & {$[0.013]$} & {$[0.012]$} & {$[0.012]$} & {$[0.014]$} & {$[0.019]$} \\
\hline ln low skilled & 0.0314 & $-0.0930^{* * *}$ & 0.000494 & $-0.0766^{* * *}$ & $-0.0486^{*}$ & $0.132^{* * *}$ & $-0.128^{* * *}$ & $0.0405^{*}$ & -0.0457 \\
\hline permanent immigrants & {$[0.038]$} & [0.013] & {$[0.017]$} & [0.018] & {$[0.027]$} & {$[0.025]$} & {$[0.022]$} & {$[0.024]$} & {$[0.042]$} \\
\hline In unemployment & $0.390^{* * *}$ & $-0.258^{* * * *}$ & $0.273^{* * *}$ & 0.0864 & -0.0131 & $0.254^{* * *}$ & $-0.321^{* * *}$ & $0.178^{*}$ & -0.121 \\
\hline rate & {$[0.14]$} & {$[0.060]$} & {$[0.052]$} & {$[0.057]$} & {$[0.100]$} & {$[0.079]$} & {$[0.098]$} & {$[0.10]$} & {$[0.14]$} \\
\hline \multirow[t]{2}{*}{ In personal income } & $0.567^{* * *}$ & $-0.272^{* * *}$ & $0.668^{* * *}$ & $0.817^{* * * *}$ & $0.398^{* *}$ & 0.105 & $0.702^{* * *}$ & $0.693^{* * *}$ & 0.0437 \\
\hline & {$[0.19]$} & [0.082] & [0.091] & {$[0.078]$} & {$[0.16]$} & {$[0.14]$} & {$[0.12]$} & {$[0.15]$} & {$[0.29]$} \\
\hline In temporary & -0.00301 & $-0.165^{* * *}$ & 0.00391 & $0.0143^{* * *}$ & -0.0162 & $0.0134^{*}$ & -0.031 & 0.00543 & 0.0224 \\
\hline Constant & [1.32] & {$[0.53]$} & {$[0.54]$} & {$[0.53]$} & {$[1.05]$} & {$[0.86]$} & {$[0.64]$} & {$[0.84]$} & {$[1.46]$} \\
\hline Observations & 276 & 784 & 782 & 686 & 560 & 770 & 865 & 290 & 117 \\
\hline R-squared & 0.56 & 0.9 & 0.98 & 0.98 & 0.91 & 0.98 & 0.86 & 0.46 & 0.98 \\
\hline
\end{tabular}

Robust standard errors in parentheses

$* * * \mathrm{p}<0.01, * * \mathrm{p}<0.05, * \mathrm{p}<0.1$

Time and sector fixed effects included in all regressions 
services contrary to permanent immigrants.

In Table 4, we add low skilled immigrant's workers specific to each sector to our specifications. Our results display a negative and significant effect of low skilled temporary immigration on prices of laundry, food preparation and serving, education and health services. Again, permanent low skilled immigrants have more controversial effects. Indeed, these workers decrease the prices of laundry, food preparation and serving, entertainment and education services but increase the prices of transport and health services.

The same opposite effects of temporary and permanent immigrants on the prices of health and transport services are found. These results support our previous findings. Temporary immigrant workers specific to each sector have significant effects only on the prices of non traded goods and services of three sectors out of nine. In addition, the effects are mitigated. They are negative only for prices of laundry services and positive for food preparation and serving and transport service. Permanent immigrant's specific to each sector increase the prices of laundry, food preparation and serving, education, and health services and decrease only the prices of entertainment services.

\section{Endogeneity issues}

A main concern in studies related to the effect of immigration on wages is reverse causality between location decisions of immigrants and wages. Indeed, relevant studies show that immigrants choose places with higher wages. Similarly, reverse causality exists also between immigrants and prices. We can imagine that immigrants could be attracted to cities because the prices are not really high. This endogeneity does not exist in the case of temporary flows because they do not choose their US locations. They must go where the employer asking for these types of workers is located. But, it might exist for permanent immigration. In order to control for this issue, the instrumentation method could be a solution. The instrument proposed here exploits the tendency of permanent immigrants to settle in a city experiencing large flows of immigration in the past. Therefore, we use the share of immigrants in 1990 per city as instrument to low skilled permanent immigration flows. This instrument is commonly used in immigration related studies (see Saiz (2006), Cortes (2006) etc.). Data from the 1990 Public Use Micro data Samples (PUMS) of the decennial Census were used to construct our instrument.

Table 5 displays results using IV techniques for each year from 2000 to 2006. 
Table 5. Prices of non-traded goods by year: IV results

\begin{tabular}{|c|c|c|c|c|c|c|c|c|}
\hline & {$[1]$} & {$[2]$} & [3] & [4] & [5] & {$[6]$} & [7] & [8] \\
\hline Year & All years & 2000 & 2001 & 2002 & 2003 & 2004 & 2005 & 2006 \\
\hline ln temporary & $-0.0308^{* * *}$ & $-0.0349^{* * *}$ & $-0.0783^{* * *}$ & $-0.0397^{* * *}$ & $-0.0253^{*}$ & -0.0197 & -0.00854 & -0.00581 \\
\hline ln low skilled & $-0.0300^{*}$ & -0.0256 & $-0.152^{* * *}$ & -0.0219 & -0.0439 & -0.0432 & -0.0303 & -0.0701 \\
\hline permanent immigrants & {$[0.017]$} & {$[0.037]$} & {$[0.053]$} & {$[0.043]$} & {$[0.046]$} & [0.049] & {$[0.058]$} & {$[0.054]$} \\
\hline ln population & $-0.257^{* * *}$ & $-0.275^{*}$ & $-0.422^{* * *}$ & $-0.282^{* *}$ & $-0.236^{*}$ & $-0.303^{* *}$ & $-0.311^{* *}$ & $-0.255^{*}$ \\
\hline ln unemployment & 0.0334 & $0.314^{* * *}$ & $0.236^{* *}$ & $0.233^{* *}$ & 0.0292 & -0.0403 & -0.168 & $-0.324^{* *}$ \\
\hline rate & {$[0.032]$} & [0.094] & {$[0.10]$} & [0.099] & {$[0.094]$} & {$[0.093]$} & {$[0.11]$} & {$[0.13]$} \\
\hline \multirow[t]{2}{*}{ In personal income } & $0.465^{* * *}$ & $0.449^{* * *}$ & $0.873^{* * *}$ & $0.470^{* * *}$ & $0.476^{* * *}$ & $0.541^{* * *}$ & $0.513^{* * *}$ & $0.543^{* * *}$ \\
\hline & {$[0.051]$} & {$[0.14]$} & {$[0.18]$} & {$[0.14]$} & {$[0.18]$} & {$[0.16]$} & {$[0.13]$} & {$[0.12]$} \\
\hline Observations & 4836 & 690 & 681 & 683 & 682 & 688 & 701 & 711 \\
\hline Cragg Donald F stat & 1471 & 479.48 & 189.89 & 372.26 & 163.03 & 111.34 & 224.99 & 235.97 \\
\hline R-squared & 0.25 & 0.31 & 0.29 & 0.27 & 0.27 & 0.25 & 0.21 & 0.2 \\
\hline
\end{tabular}

$* * * p<0.01, * * p<0.05, * p<0.1$

Time and sector fixed effects included in all regressions 
Table 6. Prices of non traded goods by sector: IV regression

\begin{tabular}{|c|c|c|c|c|c|c|c|c|c|c|}
\hline & {$[1]$} & [2] & {$[3]$} & {$[4]$} & {$[5]$} & [6] & [7] & [8] & [9] & {$[10]$} \\
\hline Sector & All sectors & Utilities & Laundry & $\begin{array}{l}\text { personal } \\
\text { care }\end{array}$ & food & $\begin{array}{c}\text { entertain- } \\
\text { ment }\end{array}$ & transport & education & health & telephone \\
\hline immigrants & {$[0.0047]$} & {$[0.029]$} & {$[0.0092]$} & {$[0.0090]$} & {$[0.0093]$} & {$[0.016]$} & {$[0.014]$} & {$[0.013]$} & {$[0.016]$} & {$[0.050]$} \\
\hline In low skilled & $-0.0300^{*}$ & 0.0875 & -0.028 & 0.0484 & $-0.112^{* * *}$ & -0.067 & $0.315^{* * *}$ & $-0.249^{* * *}$ & $0.112^{*}$ & $-0.358^{* *}$ \\
\hline permanent immigrants & {$[0.017]$} & {$[0.11]$} & {$[0.033]$} & {$[0.032]$} & {$[0.033]$} & {$[0.058]$} & {$[0.051]$} & {$[0.054]$} & {$[0.057]$} & {$[0.16]$} \\
\hline \multirow[t]{2}{*}{ In unemployment rate } & 0.0334 & $0.425^{* *}$ & -0.0925 & $0.306^{* * *}$ & 0.019 & 0.0611 & $0.370^{* * *}$ & $-0.342^{* * *}$ & 0.14 & -0.373 \\
\hline & {$[0.032]$} & {$[0.17]$} & {$[0.060]$} & {$[0.059]$} & {$[0.061]$} & {$[0.10]$} & [0.094] & {$[0.099]$} & {$[0.10]$} & {$[0.33]$} \\
\hline \multirow[t]{2}{*}{ ln personal income } & $0.465^{* * *}$ & 0.479 & -0.0346 & $0.670^{* * *}$ & $0.927^{* * *}$ & $0.479^{* * *}$ & -0.133 & $0.809^{* * *}$ & $0.571^{* * *}$ & 0.455 \\
\hline & {$[0.051]$} & {$[0.29]$} & {$[0.097]$} & {$[0.096]$} & [0.099] & {$[0.18]$} & {$[0.15]$} & {$[0.15]$} & {$[0.17]$} & {$[0.49]$} \\
\hline Observations & 4836 & 276 & 784 & 782 & 686 & 560 & 770 & 865 & 290 & 117 \\
\hline in 1990 & {$[0.011]$} & {$[0.047]$} & {$[0.029]$} & [0.029] & {$[0.031]$} & {$[0.034]$} & [0.029] & {$[0.025]$} & {$[0.047]$} & {$[0.076]$} \\
\hline Cragg Donald F stat & 1471 & 56.02 & 229 & 229.5 & 199.9 & 153.6 & 232.3 & 295.4 & 91.473 & 4.96 \\
\hline R-squared & 0.25 & 0.28 & 0.26 & 0.26 & 0.26 & 0.27 & 0.27 & 0.17 & 0.25 & 0.34 \\
\hline
\end{tabular}

Standard errors in parentheses

*** $\mathrm{p}<0.01, * * \mathrm{p}<0.05, * \mathrm{p}<0.1$

Time and sector fixed effects included in all regressions 
The instrument used for temporary immigrants is reported at the bottom of Table 5 as well as the test assessing the instrument quality. The estimated Cragg-Donald F statistics reported below the regression results consistently shows that the chosen instrument is indeed relevant. The first stage regressions show that shares of immigrants in 1990 per city is positively correlated with low skilled permanent immigrants with the former explaining $40-50 \%$ of the latter for the years presented in our panel. Column 1 presents IV results for the whole period and provides support for previous findings i.e. temporary low skilled immigration decrease prices of non traded goods and services.

This result is found for all years (see column 2 to 8 in Table 5) and corresponds to our theoretical model implications. Permanent low skilled immigration decreases also the prices of non traded goods and services. However, this type of immigration have significant effects only when the whole period is considered and for the year 2001. Similarly to previous results, population lowers prices in contrast to incomes. Unemployment rate have non significant effects when the whole period is considered and controversial effects at the year level. Indeed, results show positive effects for 2000, 2001, and 2002 and negative effects for 2006.

Table 6 display results of IV estimations for each sector. The instrument used for temporary immigrants is reported at the bottom of Table 6 as well as the test assessing the instrument quality. The estimated Cragg-Donald F statistics reported below the regression results consistently shows that the chosen instrument is indeed relevant. The first stage regressions shows that shares of immigrants in 1990 per city is positively correlated with low skilled permanent immigrants with the former explaining 4050 percent of the latter for the sectors chosen in our panel. Results in Table 6 support the negative effects of low skilled temporary immigration on the prices of laundry, food preparation and serving, education and health services. Only the prices of the transport services are positively correlated with this type of immigration. Permanent immigration effects have mixed effects on prices. Indeed, permanent immigration increases the prices of transport and health services but decreases those of food preparation and serving, education and telephone services.

\section{Conclusion}

The specific factor model presented in this paper predicts that temporary immigrants have a negative effect on the price of non-traded goods and services, 
while the effect of permanent immigrants is ambiguous and depends on whether the non tradable sector is more low skilled domestic labor intensive than the tradable sector. The empirical analysis presented in this study supports the predictions concerning the impact of temporary migration on prices of non tradable services and suggestions that the low skill domestic labor intensity of non tradable services may differ across sectors. Using information on temporary and permanent immigration and product level price data for U.S. cities during the period 20002006, we find that low skilled temporary immigrants have an overall negative impact on the relative price of non-traded goods. We find that low skilled temporary immigrants have an overall negative impact on the relative price of nontraded goods and services. The results of this paper thus give useful insights for the design of immigration policy highlighting the possible positive effects of temporary immigration on host countries. In particular, these findings confirm that immigration, like trade and offshoring, has the potential to increase welfare through the reduction of consumer and input prices.

Our findings for the non tradable sectors as a whole suggest that the effect of permanent immigration on the prices of non tradable services is also negative. These findings are in line with the findings by Cortes (2008) and in the context of our model suggest that non tradable services are overall more low skill intensive than tradable goods and services. When repeating our regressions for individual non tradable sectors, though, we find evidence that permanent immigration has a positive impact on the prices of transport and health services, suggesting that those sectors are less low skill domestic labor intensive that tradable goods or services. Our findings support the prediction in Neary (1989) that immigration may increase the prices of some non tradables due to increased demand.

The sectoral regressions confirm our prediction that temporary immigration reduces the prices of non tradable goods for all but two sectors: the effect on the prices of utilities and transport services is found to be significantly positive in some regressions. This finding is not in line with the predictions of our model and suggests that the assumptions concerning the consumption behavior of temporary migrants made in our model and in part of the relevant literature - i.e. that the temporary migrant consumption in host countries is negligible - may be oversimplistic. Unlike laundry and entertainment services, utilities and transport services are services that temporary migrants are likely to use intensively. 
Received 3 April 2010, Revised 24 October 2010, Accepted 26 October 2010

\section{References}

Blinder, A. (2009), How many u.s. jobs might be offshorable?, World Economics, 10(2), pp. 41-78.

Borjas, G. J., R. B. Freeman, and F. Katz (1992), Immigration and the Work Force: Economic Consequences for the United States and Source Areas (G. Borjas and R. Freeman ed.), Chapter on the Labor Market Effects of Immigration and Trade, Chicago: University of Chicago and NBER.

Bowen, H. P. and J. P. Wu (2006), Does It Matter Where Immigrants Work?, Traded Goods, Non-traded Goods, and Sector Specific Employment, Vlerick Leuven Gent Working Paper Series.

Card, D. (2001), Immigrant Inflows, Native Outflows, and the Local Labor Market Impacts of Higher Immigration, Journal of Labor Economics.

Carlin, W. (1996), Economic Growth in Europe since 1945 (Nicholas Crafts and Gianni Toniolo ed.)., Chapter West Germany Growth and Institutions, 1945-90. Cambridge University Press.

Cortes, P. (2008), The Effects of Low Skilled Immigration on us Prices: Evidence from CPI Data, Journal of Political Economy, 116(3), pp. 381-422.

Glaeser, E. L., J. Kolko, and A. Saiz (2001), Consumer City, Journal of Economic Geography, pp. 27-50.

Hatzipanayotou, P. (1994), Non Traded Goods, Capital Taxes, and Temporary Immigration in a Small Open Economy, International Economic Journal, 8(4).

Jensen, J. B. and L. G. Kletzer (2005), Peterson Institute for International Economics, Tradable Services: Understanding the Scope and Impact of Services Outsourcing. Peterson Institute Working Paper WP05-9.

Jones, R. W. and S. L. Engerman (2001), International Labor Flows and National Wages, Economic Development and International Trade, 87(2).

Kondoh, K. (1999), Permanent Migrants and Cross-border Workers: The Effects on The Host Country, Journal of Regional Science, 39.

Lach, S. (2007), Immigration and Prices, Journal of Political Economy, 4.

Lowell, B. L. (1999), Skilled Temporary Specialty Workers in the United States, People and Place, 7, pp. 24-32.

Mattoo, A. (2005), Services in a Development Round: Three Goals and Proposals, Journal of World Trade, 39(6), pp. 1223-1237.

Neary, P. J. (1989), Immigration and Real Wages. Economic Letters.

Pischke, J. S. (1992), Assimilation and the Earnings of Guestworkers in Germany, ZEW Discussion Papers No. 92-17.

Rahman, M. (2001), Temporary International Immigration and the Nontraded Sector of the Labor-importing Developing Countries, Journal of Economics and Finance, pp. 
125-126.

Saiz, A. (2007, March), Immigration and Housing Rents in American Cities, Journal of Urban Economics, 61(2), pp. 345-371.

Zavodny, M. (2003), The h-1b Program and Its Effects on Information Technology Workers, Federal Reserve Bank of Atlanta Economic Review.

Zimmermann, K. F., T. K. Bauer, and M. Lofstrom (2000), Immigration Policy, Assimilation of Immigrants and Natives' Sentiments Towards Immigrants, Evidence from 12 OECD-countries, IZA Discussion Paper No. 187.

\section{Appendix}

Appendix A. Descriptive statistics

\begin{tabular}{|c|c|c|c|c|c|}
\hline Variable & Obs & Mean & Std. Dev. & Min & Max \\
\hline lnprice & 4836 & 4.306929 & 2.692392 & -2.81341 & 10.19335 \\
\hline $\ln \mathrm{H} 2 \mathrm{~b}$ city & 5586 & 6.410922 & 1.806896 & 0 & 8.75621 \\
\hline In low skilled permanent flows & 5586 & 8.591747 & 1.42028 & 4.609775 & 10.9438 \\
\hline In population & 5586 & 15.34991 & 0.714034 & 13.68213 & 16.74845 \\
\hline In unemployment rate & 5586 & 1.554914 & 0.257443 & 0.828552 & 1.983756 \\
\hline ln personal income & 5586 & 18.99915 & 0.7560491 & 7.09662 & 0.65625 \\
\hline In share of immigrants in 1990 & 5586 & -14.9439 & 1.498355 & -16.7714 & -11.5658 \\
\hline $\ln \mathrm{H} 2 \mathrm{~b}$ arts & 5586 & 1.451482 & 1.980788 & 0 & 5.97381 \\
\hline ln $\mathrm{H} 2 \mathrm{~b}$ education & 5586 & 0.159043 & 0.622507 & 0 & 4.094345 \\
\hline $\ln \mathrm{H} 2 \mathrm{~b}$ food & 5586 & 1.898091 & 2.166113 & 0 & 6.182085 \\
\hline ln $\mathrm{H} 2 \mathrm{~b}$ health & 5586 & 0.441945 & 0.999876 & 0 & 4.127134 \\
\hline ln $\mathrm{H} 2 \mathrm{~b}$ care & 5586 & 3.002086 & 2.50061 & 0 & 7.193686 \\
\hline ln $\mathrm{H} 2 \mathrm{~b}$ transport & 5586 & 1.331569 & 2.05838 & 0 & 5.659482 \\
\hline $\ln \mathrm{H} 2 \mathrm{~b}$ utilities & 5586 & 1.725679 & 2.273679 & 0 & 7.933797 \\
\hline ln H2b laundry & 5586 & 0.19075 & 0.834137 & 0 & 4.204693 \\
\hline In $\mathrm{H} 2 \mathrm{~b}$ telephone & 5586 & 0.337117 & 1.097675 & 0 & 6.55108 \\
\hline ln low skilled permanent arts & 5586 & 2.738335 & 2.99629 & 0 & 7.978529 \\
\hline In low skilled permanent education & 5586 & 2.086926 & 2.618495 & 0 & 7.014323 \\
\hline In low skilled permanent food & 5586 & 4.847513 & 3.184237 & 0 & 8.66596 \\
\hline 1ln low skilled permanent health & 5586 & 2.981452 & 2.983008 & 0 & 8.368333 \\
\hline In low skilled permanent care & 5586 & 5.498217 & 2.824851 & 0 & 9.600278 \\
\hline In low skilled permanent transport & 5586 & 3.182947 & 3.327888 & 0 & 8.689395 \\
\hline In low skilled permanent utilities & 5586 & 0.948539 & 1.943504 & 0 & 5.850774 \\
\hline In low skilled permanent laundry & 5586 & 2.503943 & 2.684543 & 0 & 7.169148 \\
\hline In low skilled permanent telephone & 5586 & 0.68551 & 1.69156 & 0 & 5.924053 \\
\hline
\end{tabular}


Appendix B. Classification of Goods and Services

\begin{tabular}{|c|c|}
\hline Code & Non Traded Goods and Services \\
\hline & Telephone \\
\hline UTLR & Telephone and line, monthly rental (average) \\
\hline \multirow[t]{2}{*}{$\mathrm{UTCH}$} & Telephone, charge per local call from home ( 3 mins) (average) \\
\hline & Utilities \\
\hline UEMB & Electricity, monthly bill (average) \\
\hline UGMB & Gas, monthly bill (average) \\
\hline \multirow[t]{2}{*}{ UWMB } & Water, monthly bill (average) \\
\hline & Laundry, Cleaning, Dying, and pressing \\
\hline HLAS & Laundry (one shirt) (standard high-street outlet) \\
\hline HLAM & Laundry (one shirt) (mid-priced outlet) \\
\hline HDMS & Dry cleaning, man's suit (standard high-street outlet) \\
\hline HDMM & Dry cleaning, man's suit (mid-priced outlet) \\
\hline HDWS & Dry cleaning, woman's dress (standard high-street outlet) \\
\hline HDWM & Dry cleaning, woman's dress (mid-priced outlet) \\
\hline HDTS & Dry cleaning, trousers (standard high-street outlet) \\
\hline \multirow[t]{2}{*}{ HDTM } & Dry cleaning, trousers (mid-priced outlet) \\
\hline & Personal care and service \\
\hline $\mathrm{PCMH}$ & Man's haircut (tips included) (average) \\
\hline PCWH & Woman's cut \& blow dry (tips included) (average) \\
\hline DHDC & Hourly rate for domestic cleaning help (average) \\
\hline DHMW & Maid's monthly wages (full time) (average) \\
\hline \multirow[t]{2}{*}{ DHBR } & Babysitter's rate per hour (average) \\
\hline & Transportation and Material Moving \\
\hline TRTL & Yearly road tax or registration fee (low) \\
\hline TTUL & Cost of a tune-up (but no major repairs) (low) \\
\hline TCIL & Annual premium for car insurance (low) \\
\hline TCIH & Annual premium for car insurance (high) \\
\hline TRUP & Regular unleaded petrol (1 l) (average) \\
\hline TTIM & Taxi: initial meter charge (average) \\
\hline TTRK & Taxi rate per additional kilometre (average) \\
\hline TTAC & Taxi: airport to city centre (average) \\
\hline
\end{tabular}


Appendix B. Classification of Goods and Services (Continued)

Education, Training, and Library

ISF2

ISF3

ISF4

ISF5

ISG1

ISG2

ISG3

ISG4

ISG5

ISA1

ISA2

ISA3

ISA4

ISA5

ICGP

IXGP

ICDT

BHTH

BMHT

BDRB

BMTP

BMOP

BFFS

BCOP

RDFP

RTFP

RCFP

IGFG

ITCH

IPSP
French school: annual tuition, ages 5-12 (average)

French school: annual tuition, ages 13-17 (average)

French school: extra costs, ages 5-12 (average)

French school: extra costs, ages 13-17 (average)

French school: kindergarten annual fees (average)

German school: annual tuition, ages 5-12 (average)

German school: annual tuition, ages 13-17 (average)

German school: extra costs, ages 5-12 (average)

German school: extra costs, ages 13-17 (average)

German school: kindergarten annual fees (average)

American/English school: annual tuition, ages 5-12 (average)

American/English school: annual tuition, ages 13-17 (average)

American/English school: extra costs, ages 5-12 (average)

American/English school: extra costs, ages 13-17 (average)

American/English school: kindergarten annual fees (average)

Healthcare Practitioners and Technical Healthcare Support

Routine checkup at family doctor (average)

One X-ray at doctor's office or hospital (average)

Visit to dentist (one X-ray and one filling) (average)

Food Preparation and Serving

Hilton-type hotel, single room, one night including breakfast (average)

Moderate hotel, single room, one night including breakfast (average)

One drink at bar of first class hotel (average)

Two-course meal for two people (average)

Simple meal for one person (average)

Fast food snack: hamburger, fries and drink (average)

Arts, Design, Entertainment, Sports, and Media

One good seat at cinema (average)

Three-course dinner for four people (average)

Four best seats at theatre or concert (average)

Four best seats at cinema (average)

Green fees on a public golf course (average)

Hire of tennis court for one hour (average)

Entrance fee to a public swimming pool (average) 